\title{
Geothermal developlment in New Zealand: resource and environmental substainability
}

\begin{abstract}
This article provides a simple review of the lessons learned from some 50 years of geothermal development in New Zealand. For much more detailed information on the status of geothermal development worldwide the reader is referred to the five-volume proceedings published as part of the World Geothermal Symposium held in Florence, Italy (Barbier et al., 1995).
\end{abstract}

\section{Introduction}

Geothermal energy can be a relatively cheap resource with multiple applications and uses, from electricity generation to heating and aquiculture. Moreover, if a development is well planned and implemented a geothermal resource can be sustainable and the principle risks and environmental impacts minor. An added attraction is that $\mathrm{CO}_{2}$ emissions from a development are frequently at least an order of magnitude less than the equivalent fossil fuel development. Nevertheless, experience demonstrates that a geothermal resource is not strictly 'renewable', as energy may be extracted at over ten times the natural heat inflow resulting in a rundown of a resource due to a temperature decline and/or a fluid shortage (pressure decline).

Growth in both direct use of geothermal heat and of geothermal steam for power generation is occurring worldwide. In particular, many countries around the Pacific 'rim of fire' are encouraging new geothermal power generation. In contrast there are strong incentives in eastern Europe to replace coal-fired boilers with hot water drawn from aquifers at several kilometres depth within underlying sedimentary basins. In New Zealand the pioneering geothermal developments during the 1950s and 1960 s were followed by a lull during the 1970 s and 1980 s when the energy priorities shifted to using the large Maui natural gas field. However, with the impending depletion of the Maui resource early next century New Zealand is experiencing a revival of interest in geothermal energy with many new developments planned. This interest is boosted by a continued growth in electricity demand of over $2 \%$ per year and government encouraged competition in the energy sector and associated privitisation policies.

\section{Development history}

In New Zealand the geothermal resource is concentrated near the centre of the North Island, in the Taupo Volcanic Zone where all of NZ's active volcanoes are located (Figure. 1; Thain and Freeston, 1995). A small geothermal centre is located at Ngwha in Northland, and there are hot springs related to active faults throughout both the North and South Islands. Geothermal fields in the Taupo Volcanic Zone occur in a relatively populated region of low to moderate relief in topography, ranging from undeveloped native forest land to dairying and sheepfarming, and to exotic forestry which has been estab- lished over the past 60 years. Some fields occur within major provincial cities such as Rotorua and Taupo.

Geothermal fields were used by Maori for cooking, bathing and health. From the middle 1800 s European settlers added tourism to these practical uses. In 1957 the Kawerau Field was developed for industrial usage in a paper and pulp mill. Development for electricity generation commenced in 1950 with investigations and construction by Government agencies, notably Ministry of Works and Development and the Department of Scientific and Industrial Research. The first electricity generation station of $180 \mathrm{MW}$ capacity was established at Wairakei and produced electricity in 1959. Subsequently, this station has been derated to $157 \mathrm{MW}$. A second major government geothermal generation station of $114 \mathrm{MW}$ capacity at Ohaaki was opened in 1989.

In April, 1993, the electricity generation and supply industry in NZ was deregulated. This move, and associated changes in government policy and restructuring of government departments, completely changed the geothermal scene and opened-up opportunities for private energy suppliers and developers. As a result there are now at least eight companies or consortia planning to or in the process of constructing mainly small scale $(<50 \mathrm{MW})$ geothermal electricity generation plants. A $50 \mathrm{MW}$ power plant has just been commissioned on the flank of the Wairakei Field, a $25 \mathrm{MW}$ plant is presently being constructed at Rotokawa Field, and plans are well advanced for plants on the Tauhara and Mokai fields. Many of these are on a staged or modular basis, and several involve multiple applications including dry steam for timber and agricultural process heat. Although the waste hot water from a geothermal power plant generally has little value for the power developer this multiple use provides much more efficient use of the resource as well as local societal benefits such as employment opportunities.

At present, some $7 \%$ of NZ total electricity generation (33000 $\mathrm{GWh} /$ year) is provided by geothermal energy and this proportion is exceeding only by the Philippines (20\%), El Salvador (13\%) and Costa Rica $(9 \%)$. For NZ, the geothermally produced electricity is expected to rise to over $10 \%$ over the next 20 years (Allis, 1996). It has been estimated that the geothermal energy potential is 20000 Peta Joules (PJ), second only to coal at 140000 PJs and well ahead of natural gas/oil/condensate at $4800 \mathrm{PJs}$ and hydro-electricity at 260 $\mathrm{PJ} /$ year (maximum). In NZ most of the easy-to-develop large hydro dam sites have been utilised and the use of geothermal energy for electricity generation exceeds by an order of magnitude that for direct heat applications, in contrast to the position in many countries (e. g. China).

New Zealand's experiences in geothermal power generation over the past 50 years, summarised in the following sections, are in many cases also applicable to low-temperature, direct-heat developments.

\section{A Geothermal system}

A geothermal system, or field, consists of four subsystems (Figure 2):

- a heat source (extending to below economically drillable depths);

- a reservoir area of hot water and/or steam (which is tapped by production drilling);

- surface discharge areas (natural or man-made); 

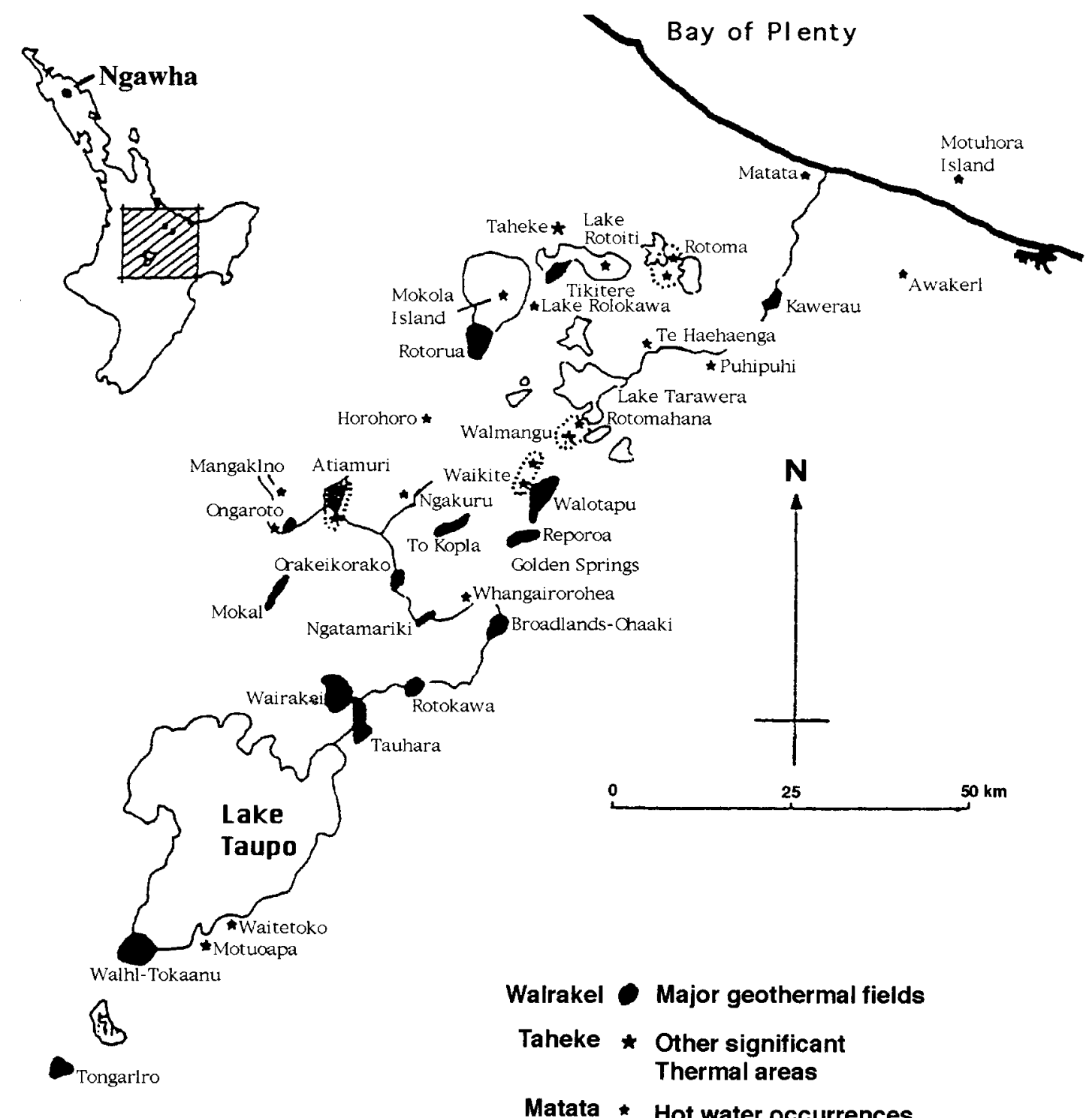

- Crater Lake

Matata * Hot water occurrences

Figure 1 Major geothermal fields, thermal areas and hot water occurrences in the Taupo Volcanic Zone, North Island, New Zealand.

- fluid recharge areas (natural or from reinjection wells).

In prospects suitable for power generation, hot water or steam at $200-300^{\circ} \mathrm{C}$ is tapped by production wells at $1-3 \mathrm{~km}$ depth. The high pressure hot water is flashed to steam in surface separators, and the steam passed through a turbine to generate electricity. The waste hot water may be used in a secondary flash plant to generate further electricity, and there also may be other direct-heat uses made of the lower temperature water (e. g. in aquiculture, horticulture, district heating, etc.). Because of its mineral content the waste water is finally disposed of in reinjection wells best located in the outer parts of a geothermal field.

In prospects suitable only for direct-heat applications, reservoirs are typically less than $120^{\circ} \mathrm{C}$. These prospects may be the out flow zone of a hot spring system at depths less than $100 \mathrm{~m}$, or aquifers at up to several kilometres depth in a sedimentary basin.

It should be noted that the geological setting (stratigraphy, structure, lithological characteristics, etc.) of a geothermal field may vary significantly and, along with the geological history, should be well understood before drilling and/or development commences in part to mitigate risks.

\section{Geothermal resource sustainability}

On today's technology and economics there is extensive evidence to demonstrate that the geothermal resource is not strictly renewable. Most power developments extract energy at over ten times the natural heat inflow. Consequently, rundown of the resource occurs, usually in the form of a temperature decline (e. g. Wairakei and Ohaaki, NZ) but occasionally a fluid shortage (pressure decline) dominates (e. g. The Geysers, USA).

Principal factors influencing sustainability are:

- the area and thickness of the high temperature resource;

- the ease with which fluids flow through the resource (ie permeability);

- the rate of temperature and/or pressure decline due to lower natural heat inflow than the extraction rate;

- scale of the development, with large scale developments being not as sustainable as small scale developments;

- economics of scale conflicting with sustainability;

- location and economics of new production wells to counter normal rundown after the first few years;

- location of reinjection wells sufficiently far from production wells to minimise or avoid cooling effects; 
- knowledge of the chemistry of fluids to facilitate maintenance of plant, promote secondary uses and mitigate environmental problems.

To maintain a geothermal resource, careful planning is required. This should be based on a detailed understanding of the geothermal ficld/system, and accompanied by ongoing reservoir monitoring, management and maintenance expenditure, including for new production or reinjection wells as necessary.

\section{Development of a geothermal resource}

Key factors influencing the development of a resource can be considered under two stages: prior to drilling and the drilling stage.

\section{Prior to drilling}

Prior to drilling, a thorough evaluation and inventory of all surface signatures of the resource is essential. These include geological evidence for geothermal activity, the evidence for high temperatures at depth, such as the type and intensity of thermal activity, and the natural heat flow. The geochemistry of the surface fluids and geothermometer estimates also provide insight to subsurface conditions. Early in the evaluation process, electrical resistivity surveying of the prospect area is critical for assessing the possible resource area. This survey needs to take into consideration probable extensions of the subsurface resource into regions of higher topography. In steep (volcanic) terrain this can be difficult, but a relatively small amount of extra expenditure at this stage of a project is preferable to delineation by step-out drilling.

Table I Key factors to be considered prior to drilling of a potential geothermal resource.

$\begin{array}{ll}\text { Geology } & \begin{array}{l}\text { young volcanism } \\ \text { active hydrothermal system } \\ \text { maximum temperature flows } \\ \text { output } \\ \text { area }\end{array} \\ \text { Geochemistry } & \begin{array}{l}\text { nature of waters \& gases } \\ \text { geothermometry }\end{array} \\ \text { Geophysics } & \begin{array}{l}\text { resistivity surveys } \\ \text { probable and possible area } \\ \text { buried structure }\end{array}\end{array}$

$=$ CONCEPTUAL MODEL

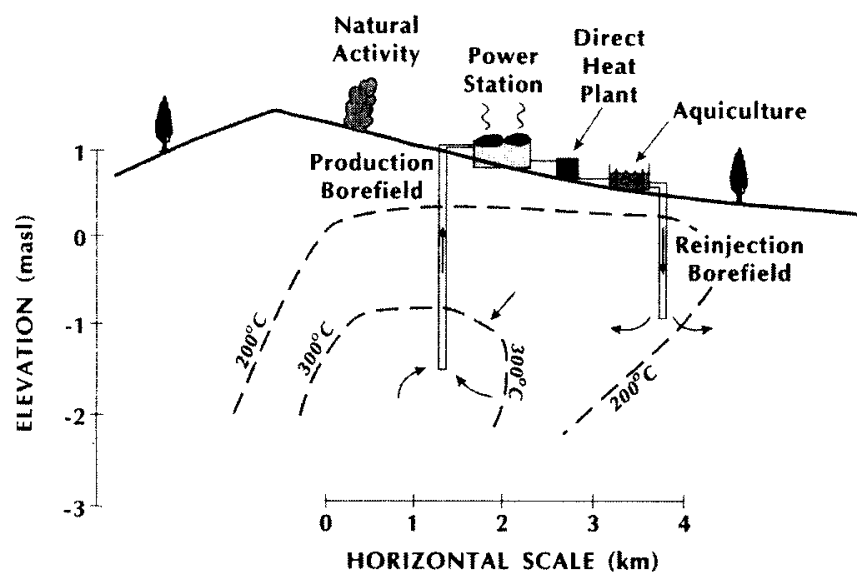

Figure 2: Sketch of major components of a geothermal system and development. (From Thain and Freeston, 1995)
A conceptual model of the field should be made at this time, and this should have sufficient information to compare the resource characteristics to other proven fields around the world. The model should be compatible with the local hydrology, and should include probable upflow and outflow zones. A 'possible' estimate of resource potential can be made, but at least a factor of two uncertainty will be present. Some simple 'stored heat' calculations can be carried out. These usually suggest development sizes of between 7-15 MWe potential per $\mathrm{km}^{2}$ area of inferred high temperature resource (depending on the proposed development life and extraction efficiency assumptions).

\section{Drilling stage (Table 2)}

Once the project has reached the well drilling stage, a further set of factors need to be considered systematically. The wells need to confirm the productive reservoir location, its characteristics, and some initial indication of likely extent (by comparison with electrical survey results). Discharge tests (preferably for weeks at a time) are needed to estimate the productivity and fluid composition of the reservoir. Decisions on the size of a first stage of development depend on the uncertainties in the reservoir size in comparison to the size of the stage. Proven production of $30-50 \%$ of the development stage is prudent. The construction of a numerical reservoir model (simulator) for predictions of reservoir performance is standard practice these days. This model will initially be simple when reservoir data is lacking, and should be continually modified and enhanced as new well and production information becomes available.

Table 2 Key factors to be considered during the drilling and development of a potential geothermal resource.

Well data

temperature and pressure trends productivity/injectivity permeability/porosity distribution fluid chemistry reservoir area

\section{$=$ RESERVOIR MODEL}

Development factors cultural, religious national park volcanic risk conflicting land use relief, slope stability, floods tourist remoteness environmental risks (eg subsidence)

$=$ DEVELOPMENT PLAN

\section{Development factors and risks}

These stages completed the principal risks with geothermal development can be summarised as (after Sanyal and Koenig, 1995):

- resource uncertainties (capacity, boundary conditions, rate of rundown);

- reinjection uncertainties;

- development size (of power station for sustainable development);

- construction uncertainties;

- management and environmental legal risks;

- electricity price trends and use;

- financing and interest/inflation rate trends.

By far the largest uncertainty is the resource risk, especially the subsurface boundary conditions related to permeability, cool water 
invasion zones, reinjection location and the location of the high temperature zones. The cost of drilling for new production wells and reinjection wells is expensive, as are long pipelines for safe, longterm reinjection. The factors of resource sustainability and resource risk both favour a staged development approach, with the actual sizing of the stages depending on reservoir knowledge and performance (Girelli et al., 1995). Experience indicates that it takes around ten years for boundary effects to become apparent and for potential long term production problems to be revealed.

The history of geothermal development in NZ-particularly over the past 10 years demonstrates well the impacts of non-resource factors (Table 3), including changes in government policy, environmental concerns and financial factors as listed in Table 3. Deregulation and privatisation of electricity generation and supply, coupled with associated reactions by consumer suppliers and competitors (Thain and Freeston 1995), declining known alternative sources of energy, developing new sources and environmental management legislation (McLeod, 1995) have had significant impacts.

\section{Table 3 Major non-geothermal resource factors influencing geo- thermal development in New Zealand}

- deregulation of the electricity generation and supply industry (since 1/4/1993) to:

-market driven

-open generation with no government monopoly

-increasing diversification of suppliers and users;

- low wholesale energy price deterring new development;

- looming short-fall in supply due to inereased demand;

- risk of supply failure due to government removing the responsibility for complete supply by its SOEs, ECNZ and Contact Energy;

- local supply to avoid transmission costs;

- strong competition from the natural gas industry;

- gas reserves being depleted;

- increasing viability of wind generation, and other alternative sources:

- requirements of the Resource Management Act (1991) for minimum environmental impact, sustainability and consultation with Maori.

The sizing of power stations for sustainable production requires careful assessment. Although the main risk is in maintaining the resource capacity to minimise the rate of decline, attention to other factors (Table 4) is necessary if long-term sustainable utilisation at economic levels is to be achieved.

Table 4 Factors influencing the sizing of geothermal power stations for sustainable development.

- main risk is resource capacity and rate of rundown

- economies of scale minor

- early generation relatively easy

- tendency to oversize development if maximising NPV cash flow dominates sizing

- stage development over $\sim 10$ years $50-100 \mathrm{MW}$ stages depending on field size

- prove significant fraction of each stage before commitment to plant

- proving reinjection scheme critical

\section{Geothermal environmental impacts}

Generally, the impacts (Table 5) are minor compared to other energy sources if the development is well planned and the operation well managed and monitored.
In fields with significant hot spring activity, changes in activity are common. The hydrological drawdown at reservoir depths prevents deep hot water from reaching the surface. However increased steam flows to the surface may occur (Allis, 1981), and in areas of intense fumarolic activity, the risk of hydrothermal eruptions is increased. Fields with shallow, hot water outflow zones, may have an increased risk of subsidence caused by drawdown. In the most extreme case, over $13 \mathrm{~m}$ of subsidence has occurred in a $1 \mathrm{~km}^{2}$ area of Wairakei field (Allis, 1990). Seismic activity may be induced around deep injection wells. No damaging events have been reported from such activity, but it usually warrants micro-earthquake monitoring. There may be increased steam discharge from the power station condenser units, and during times of high humidity in cold weather, this may contribute to local fog. Noise, dust and visual impacts are local and not normally problems. With reinjection waste disposal of the cool waters is largely subsurface and into the flanks of the field. However, surface disposal is still carried out in some fields and can create mineral pollution or hot water problems. The main environmental advantage of geothermal is the relatively low $\mathrm{CO}_{2}$ concentration in atmospheric discharges-usually an order of magnitude less per MW than for fossil fuel power plants. This relatively low $\mathrm{CO}_{2}$ emission may bring significant benefits through carbon tax avoidance (if such a tax is implemented).

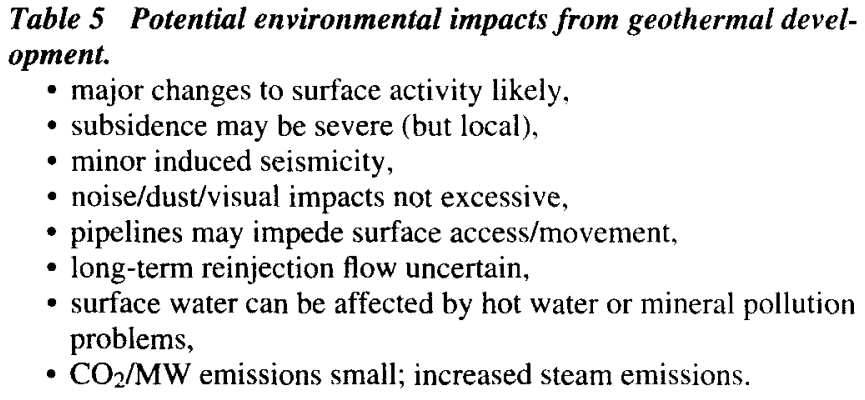

\section{Conclusions}

Much of the success in developing and applying geothermal energy in New Zealand, and world-wide, depends on four key factors:

- thorough understanding of the properties and behaviour of the reservoirs;

- close teamwork between scientists, engineers and drillers at all stages of investigation, development and production;

- continuing monitoring and management of reservoirs, and prompt reaction to problems;

- recognition and prompt resolution of problems which are often unique to a field and its fluids.

Experience is also demonstrating that multiple application/uses (electricity generation to aquiculture) increase the economic returns and benefits, and that staged development is a sound strategy. Geothermal energy can be an environmentally friendly and relatively cheap, alternative source of energy in those countries with active geothermal systems, especially if such systems are close to population centres or major industries.

\section{Acknowledgements}

This paper summaries a contribution designed for non-specialist audience and presented by Ian Speden at a workshop on Geology and Sustainable Development held in Santiago, Chile, on the 6 January 1997. It is based on papers and information provided by colleagues in the Institute of Geological and Nuclear Sciences; special thanks are due to Drs Greg Arehart, Trevor Hunt and Mike Mongillo. 


\section{References}

Allis, R.G. 1990. Subsidence at Wairakei Field. Geothermal Resources Council, Transactions, 14(2), 1081-1087.

Allis, R.G. 1996. Update to geothermal development in New Zealand. Proceedings international symposium on high temperature geothermal development and utilisation, Kunming, China, April 23-29 1996.

Barbier, E., Frye, C.T. et al. 1995. Proceedings of the World Geothermal Congress, Florence, Italy. World Geothermal Association, 5 volumes and 3028 pages.

Girelli, M., Parini, M., Pisani, P. 1995. Economic evaluations of alternative strategies of Geothermal Exploitation. Transactions International Geothermal Energy Conference, Florence, Italy, 2843-2846.

McLeod, J.T. 1995. Sustainable management of geothermal resources, a New Zealand scenario. Proceedings International Geothermal Symposium, Italy, 1995, 569-573.

Sanyal, S.K., Koenig, J.B. 1995. Resource risk and its mitigation for the financing of geothermal projects. Transactions International Geothermal Energy Conference, Florence, Italy, 2911-2915.

Thain, 1.A., Freeston, D.H. 1995. 1990-1995. update report on the existing and planned utilisation of geothermal energy for electricity generation and direct heat use in New Zealand. Proceedings International Geothermal Symposium, Italy, 1995, 283-288.
Ian Speden is a Research Associate at the Institute of Geological and Nuclear Sciences, Lower Hutt, New Zealand, and a Vice-President of the International Union of Geological Sciences. A past director of NZ Geological Survey and DSIR Geology and Geophysics he is currently undertaking research on the structure and stratigraphy of the Raukumara Peninsula region of the North Island of $N Z$.

Rick Allis is currently Group Manager of Earth Resources at the Institute of Geological and Nuclear Sciences, Lower Hutt, NZ. He received $a \mathrm{PhD}$ at the University of Toronto in 1977, and spent 12 years researching geothermal processes at Wairakei. His current interests include thermal modelling of basin evolution, and the effects of development on geothermal systems.
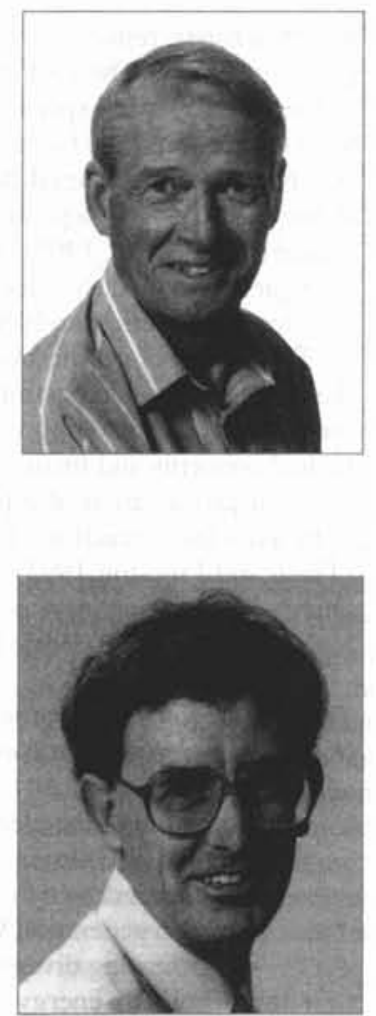

\section{Episodes is your window to the world. Subscribe today!} Episodes

\section{Subcription Order}

Name (please print)

Address

\begin{tabular}{ll} 
City $\_$State/Prov. \\
Country $\quad$ Zip/Postal Code \\
\hline
\end{tabular}

Please begin my subscription:

$$
\begin{array}{llll}
\text { March } & \text { June } & \text { Sept. } & \text { Dec. } \\
\text { Year } & \text { Year } & \text { Year } & \text { Year }
\end{array}
$$

To start your subscription, fill in this form and mail to:

\section{Episodes}

P.O. Box 823

26 Baiwanzhuang Rd.,

Beijing 100037, China

Tel: +86-10-6832 0827; +86-10-6832 7772

Fax: +86-10-6832 8928

E-mail:episodes@public.east.cn.net igcbj@public3.bta.net.cn
Payment may be made by:

- Checks (US \$ only) made payable to Episodes

- $\square$ Diners $\square$ JCB $\square$ Visa

\section{$\square$ American Express $\square$ Mastercard}

Please quote account number, expiry date and signature

Account\#

Expiry date

Signature

Annual subscription rates:US\$24 